DOI 10.4467/2543733XSSB.17.010.9985

\author{
KAROL BIENIEK
}

Institute of Law, Administration and Economics

Pedagogical University of Cracow

\title{
THE RETURN OF THE EMPIRE? THE FOREIGN POLICY OF TURKEY IN THE JUSTICE AND DEVELOPMENT PARTY (AKP) ERA AND ITS INFLUENCE ON THE MODERN ALBANIAN STATE
}

\begin{abstract}
Summary
The "strategic depth" paradigm implemented by the AKP, in general aimed at strengthening Turkey's role in the region, is perceived both as clear pragmatism in foreign policy making and a tool for the neo-ottoman expansion. This paper argues that current foreign policy of Turkey towards Albania is reminiscent of the Kemalist foreign policy towards this country but at the same time it represents a new quality, immanent for the AKP's perception of international relations. While analyzing Turkey's influence in the various spheres and the outcomes of Ankara's foreign policy, this paper seeks to verify the hypothesis that the modern bilateral relations of these two countries shall be perceived rather both as AKP's pragmatic stance, with possible neo-Ottoman ambitions playing an important role.
\end{abstract}

Keywords: Turkey, foreign policy, strategic depth, Albania, AKP

\section{Introduction}

The traditionally good bilateral relations of Turkey and Albania in the post-Cold War period experienced a new impetus in the Justice and Development Party (Adalet ve Kalkınma Partisi, AKP) era. This party, which has been ruling Turkey since 2002, established a new frameworks of country's foreign policy mainly based on the "strategic depth" conception. This paradigm, in general aimed at strengthening Turkey's role in the region, is perceived both as clear pragmatism in foreign policy making and a tool for the neo-Ottoman expansion. This paper argues that current foreign policy of Turkey towards Albania is reminiscent of the Kemalist foreign policy towards this country but at the same time it represents a new 
quality, immanent for the AKP's perception of international relations. While analyzing Turkey's influence in the various spheres and the outcomes of Ankara's foreign policy, this paper seeks to verify the hypothesis that the modern bilateral relations of these two countries shall be perceived rather both as AKP's pragmatic stance, with possible neo-Ottoman ambitions playing an important role.

This paper consist of three fundamental parts. In the first one the AKP's attitude towards the Balkans is described with reference to Turkey's historical role in the Balkan Peninsula and the shift in the country's foreign policy. This change is strictly linked with the implementation of the "strategic depth" concept which resettled Turkish foreign policy in general. The second part refers to the bilateral relations between Turkey and Albania during the AKP's rule. It describes how bilateral relations evolved in the context of having "strategic depth" in use. Conclusions are presented in the last part.

This analysis is theoretically anchored in the national role concepts developed by K.J. Holsti who indicated that "Role theory thus emphasizes the interaction between the role prescription of the alter and the role performance of the occupant of a position (ego)"1. He claims that every decision in foreign policy making is primarily derived from several factors such asL the policymakers' role concepts, domestic needs and demands, and also critical events in the external environment ${ }^{2}$. Thus, the national role's performance is defined as the general "foreign policy behavior of governments which includes patterns of attitudes, decisions, responses, functions and commitments towards the other states"' . What is even more important, Holsti names the mentioned patterns or typical decisions as national roles and stipulates that national roles concept “....includes the policymakers'own definitions of the general kinds of decisions, commitments, rules and actions suitable to their state, and of the functions, if any, their state should perform on a continuing basis in the international system or in subordinate regional systems. It is their "image" of the appropriate orientations or functions of their state toward, or in, the external environment" 4 . In his conceptualization Holsti identifies several examples of national role concepts. It is interesting to see how Turkey's attitude towards the Balkans, towards Albania and also Turkish foreign policy in general, fit Holsti's particular type of the national role since this paper argues that all together combine the features of regional protector role and an active independent one. The first one "... though it perhaps implies special leadership responsibilities on a regional or issue-area basis, places emphasis on the function of providing protection for adjacent region" while the second one "...emphasizes at once independence, self-determination, possible mediation functions, and active programs to extend diplomatic and commercial relations to diverse areas of the word".

The AKP's highly pragmatic Turkish foreign policy towards the Balkans remains in harmony with the cautious Kemalist policy towards the region after the end of the Cold War thus being settled within the regional protector role. On the other hand, all of the AKP's “strategic depth" concept necessities Turkey's activism both in the terms of trade

${ }^{1}$ K.J. Holsti, National Role Conceptions in the Study of Foreign Policy, International Studies Quarterly, Vol. 14, No. 3, 1970, p. 239.

${ }^{2}$ Ibidem, p. 243.

${ }^{3}$ Ibidem, p. 243.

${ }^{4}$ Ibidem, p. 245-246.

${ }^{5}$ Ibidem, p. 261-262. 
and diplomatic activities. What is more, since Turkish foreign policy in the AKP's era is also a tool for creating this party's domestic identity, role theory is a useful analytical tool for capturing different policy choices among many alternatives. It also clarifies Turkey's particular decisions and actions while it helps to catch the link between the agent, the entire structure and the former's subjective perceptions - the AKP's subjective perceptions of the country's power (economical, military, political etc.), towards other states in the Balkan region.

\section{Justice and Development Party and the Balkans}

The much of the Balkans was under Ottoman rule from almost the 14th century up until the early 1920s when the Ottoman Empire collapsed. The creation of the modern Republic of Turkey in 1923 ended the period of Ottoman dominance and presence in the region. The newly established state must have changed its foreign policy and adopted a highly moderated and cautious approach towards the neighboring countries. While the Kemalist elite implemented crucial modernizing domestic reforms, the relations with the Balkan countries were limited to the formal ones and performed within the context of traditional diplomacy, thus the entire region remained a rather distant territory for Ankara. The Cold War and Turkey's 1952 NATO accession made this distance even longer while the Balkan countries shared a communist ideology and/or remained under Soviet influence. The end of the Cold War and crucial changes in the international environment started to dynamically change these relations since Turkey was to search for its new role in the international community ${ }^{6}$. In the 1990s Turkey, despite some reservations, decided to contribute actively to the peace processes in the Balkans within the European Union and the United Nations frameworks?

The end of the Cold War was also crucial for Albanian foreign policy making. During the communist rule, equated to Enver Hoxha's leadership, ideology was an important factor of the country's relations with the external world however together with the end of the Cold War, Albania became interested in developing political, economic and cultural relations especially with Turkey, Israel and the Arab states of the Persian Gulf ${ }^{8}$.

The AKP's electoral success in the 2002 marked an important rise in the interest in the Balkans combined with the shift in the traditional foreign policy of Turkey. The new principles of the Turkish foreign policy making were provided by Ahmet Davutoğlu in his famous book entitled "Strategic Depth: Turkey's International Position", published in 2001. According to Davutoğlu, two factors are crucial determinants of foreign policy i.e. geography and the history thus anchoring it in the Turkey's Ottoman presence and power in particular regions surrounding the country ${ }^{9}$. From now on Turkish foreign policy, also towards the Balkans, should be considered as a continuation of the existing geographical,

${ }^{6}$ M. Türkeş, İ. Uzgel, Türkiye'nin komşularl, Ankara 2002, p. 9.

${ }^{7}$ See: M. Türkeş, Türkiye 'nin Balkan Politikasında Devamlık ve Değişim, Avrasya Dosyası, Vol. 14, No. 1, 2008, pp. 253-280.

${ }^{8}$ M.B. Bishku, Albania and the Middle East, Mediterranean Quarterly, 24, (2.), 2013, p. 84.

${ }^{9}$ A. Davutoğlu, Stratejik Derinlik. Türkiye'nin Uluslararası Konumu, İstanbul 2001, p. 321. 
historical and cultural links ${ }^{10}$ and should be performed, as Davutoğlu later defined, in accordance with five basic principles: a) a balance between security and democracy, b) a zero-problem strategy towards the neighbors, c) the development of relations with the neighboring regions and beyond, d) adherence to a multidimensional foreign policy, e) rhythmic diplomacy ${ }^{11}$. Referring directly to the Balkan Peninsula Davutoğlu wrote: "The will has emerged to transform the natural accumulation of a common religious-historical legacy in majority Muslim (Bosnia and Albania) into a natural alliance with Turkey. The Turkish and Muslim minorities in Bulgaria, Greece, Macedonia, Sanjak, Kosovo and Romania are also important elements of Turkey's Balkan policy"12. The new activism in Turkey's Balkan policy overlapped in frequent high-level diplomatic visits, social and cultural exchanges, however with minor change in trade relations while Turkey was unable to compete successfully with European states ${ }^{13}$. Later, the positive and active attitude towards the Balkans reached its climax in 2009 when Davutoğlu referred directly to the Ottoman legacy. At the opening ceremony of the "Ottoman Legacy and Balkan Muslim Communities Today" Conference (October 2009, Sarajevo) he stated: "I am underlining... the Ottoman legacy. The Ottoman centuries of the Balkans were success stories. Now, we have to reinvent this...we will make the Balkans, Caucasus, Middle East, together with Turkey, the center of world politics in the future. This is the objective of Turkish foreign policy, and we will achieve this"14. Also, President Recep Tayyip Erdoğan expressed his affection towards the region during his post-election speech on 30 March 2014: "I wholeheartedly greet our 81 provinces as well as sister and friendly capitals and cities of the world from Ankara, from the AK Party headquarters. I've just addressed via teleconference thousands of people who gathered in Skopje Square. They were sharing the joy you have here in freezing weather. I first want to express my absolute gratitude to my God for such a victory and a meaningful result. I thank my friends and brothers all over the world who prayed for our victory. I thank my brothers in Palestine who saw our victory as their victory. I thank my brothers in Egypt who are struggling for democracy and who understand our struggle very well. I thank my brothers in the Balkans, in Bosnia, in Macedonia, in Kosovo and in all cities in Europe who celebrate our victory with the same joy we have here" $" 15$.

Despite this, the optimistic approach and general Turkish enthusiasm, the reality of relations with the Balkans differs. General change in the foreign policy, mainly the "strategic depth" conception did not overlap with the aspirations and expectations of several countries. What is more, since 2009, one can observe a radicalization of the neo-Ottoman

${ }^{10}$ H. Kramer, A Changing Turkey: The Challenge to Europe and the United States, Washington 2000, p. 147.

${ }^{11}$ A. Davutoğlu, Türkiye merkez ülke olmal, Radikal 2004, (online:) http://www.radikal.com.tr/yorum/ turkiye-merkez-ulke-olmali-702116/, (accessed: 09.12.2016).

${ }^{12}$ A. Davutoğlu, Stratejik Derinlik..., p. 123.

${ }^{13} \mathrm{M}$. Akoğlu Şişman, East European countries and Turkey vis-à-vis the EU: a comparative analysis of commercial relations, METU Studies in Development, Vol. 41, No. 3, 2014, p. 435.

${ }^{14} \mathrm{~A}$. Davutoğlu, Speech on the opening ceremony of the Ottoman Legacy and Balkan Muslim Communities Today Conference, Sarajevo, 16.10.2009.

${ }^{15}$ R.T. Erdoğan's Speech (30.03.2014, Ankara), http://www.hurriyetdailynews.com/full-text-turkish-pmerdogans-post-election-balcony-speech.aspx?pageID $=238 \& n I D=64341 \&$ News CatID $=338$ (accessed: 20.01.2017). 
attitude. This came both with Davutoğlu's Sarajevo Speech and the infamous "One Minute" demarche in Davos in January 2009 of Recep Tayyip Erdoğan. Storming out of the Davos meeting and blaming Israel for the murdering of Palestinians deteriorated Turkish-Israeli relations and also revealed Ankara's broad aspirations in the international environment. In fact, this step marked a turning point in terms of Turkey's engagement in the neighboring regions. In the case of the Balkans, one can clearly observe a gap between Turkish aspirations and abilities on the one hand, and the attitude of the particular countries which are the receivers of this policy on the other. This is also the case of Turkish-Albanian relations.

\section{Turkish-Albanian Relations in the Justice and Development Party Era}

The overall good bilateral relations of the two countries started long before 2002, when AKP came into power. The Agreement on Trade in 1986 and the Agreement on Economic, Commercial, Industrial and Technical Cooperation of 1988 set the foundations for economic cooperation and the development of commercial relations. Military cooperation also started in the early 1990s - a defense cooperation pact between the two countries was signed on 29 July 1992 and from then on Turkey played an active and important role in the training of Albanian officers ${ }^{16}$.

During the AKP's rule Albania and Turkey have further developed bilateral relations, especially in terms of the economy. According to new principles of Turkish foreign policy, the promotion of trade and investments shall be perceived as the next stage of international activism - a transformation into a "trading state" is a tool for achieving aims in the external environment ${ }^{17}$. An increase of trade exchange while having AKP in power is clearly visible: In 2002, the value of Turkish export to Albania was USD 79.76 million, and import was USD 3.97 million. In 2008, import reached USD 305.74 million, and export was USD 36.7 million whereas in 2016 both values were USD 304,611 million and USD 20,602 million respectively ${ }^{18}$. Among top Turkish export categories on can find: iron and steel, textile yarn, made-up articles, cereals and cereal preparations, electrical machinery, clothing apparel and accessories while top import categories from Albania include: hides, fur skins, raw, transport equipment and plastics ${ }^{19}$. The total trade balance between the two countries is unequal, in 2016 it reached a USD 284,009 surplus for Turkey ${ }^{20}$. Turkish business is widely represented in Albania; according to president Erdoğan, for 2015, investments in Albania has exceeded USD 2.7 billion- during his visit in Albania in May 2015 while attending the Turkey-Albania Business Forum with President Nishani of Albania, Erdoğan said: "I am asking Turkish investors to increase these investments even more. Our firms operate in a wide array of sectors ranging from banking, mining, port management,

${ }^{16}$ İ. Uzgel, Balkanlarla İlişkiler, in: Türk Dış Politikası. Kurtuluş Savaşından Bügüne Olgular, Belgeler, Yorumlar, Cilt II 1980-2001, B. Oran (ed.), İstanbul 2005, p. 503.

${ }^{17}$ See: K. Kirişci, The Transformation of Turkish Foreign Policy: The Rise of the Trading State, New Perspectives on Turkey, No. 40, 2009, pp. 29-57.

${ }^{18}$ Turkish Statistical Institute Data, www.tuik.gov.tr, (accessed: 12.01.2017).

${ }^{19}$ Ibidem.

${ }^{20}$ Ibidem. 
energy, logistics and food industry. Our firms provide 8 thousand jobs. It is significant but not enough. I believe we should further improve, deepen and diversify our economic and commercial relations on the basis of mutual benefit. We need to elevate our trade volume beyond the $\$ 1$ billion goal ${ }^{21}$. He also stipulated that the number of Albanian tourists to Turkey has reached 80 thousand and underlined cooperation with Albania in the international structures: "We regard Albania as our neighbor even though we do not share a border. Political leaders know very well how we supported Albania in military area, in NATO. We are two friendly, brotherly countries in NATO"22.

The Turkish government is also facilitating strong cultural ties with Albania, mainly through the Turkish Cooperation and Coordinator Agency (Türk İşbirliği ve Koordinasyon Ajansı, TIKA) which works within the framework of Republic of Turkey Prime Ministry. While influence in the cultural sphere remains one of the most important tools, among many in the "strategic depth" paradigm, TIKA is permanently committed to the restoration of mosques, bazaars and other historical facilities from the Ottoman period in Albania ${ }^{23}$. According to the Turkish Ministry of Foreign Affairs, TiKA participated in 430 projects in Albania and has spent around USD 85 million for its development help ${ }^{24}$. The fact that both Turkish and Albanian Sunni Muslims follow the Hanafi school of Islamic law makes Turkey's cultural presence in Albania even easier, thus paving the way for vigorous student exchange between two countries.

In fact, Erdoğan's visit in 2015 was not limited only to underlying and praising of good bilateral relations while he brought Turkey's domestic problems to the scene, mainly the Gülen group. Together with the split with his former political ally, F. Gülen, in 2013 Erdoğan accused him of creating "a state within the state" in Turkey and announced that educational facilities run by the Gülen should be closed down ${ }^{25}$. During his visit, President Erdoğan requested Albanian government officials to close down the Gülen schools in return for Turkey's gift of recently opened mosque. This claim was perceived by the Albanian political elite as a clear example of neo-Ottoman aspirations and created fury in the country's domestic politics - Erdoğan has been criticized by almost all political options. Harsh and significant critique came from Albanian ex-prime minister and prominent figure in domestic politics, Sali Berisha who said that:

"The declaration of President Erdoğan about Moslem brothers from the Adriatic Sea to the Chinese Wall was a declaration that does not match with the Albanian reality. We are a multi-religious nation. In this context, any declaration with religious nuances, from any Muslim leader or Christian, has to take into consideration that he or she will be welcomed only if he or she is accepted consensually, if he or she is does not hurt any Albanian with other beliefs. In comparison with many other nations, religion has never been

${ }^{21}$ R.T. Erdoğan's Speech (13.05.2015, Tirana), http://www.tccb.gov.tr/yurt-disi-ziyaretler/355/32313/arnavutluk.html, (accessed: 13.01.2017).

${ }^{22}$ Ibidem.

${ }^{23}$ Arnavutluk Başbakanı Edi Rama Berat'ta TiKA'nın Restorasyon Projelerini Inceledi, http://www.tika.gov. $\mathrm{tr} / \mathrm{tr} / \mathrm{haber} / \mathrm{arnavutluk}$ basbakani_edi_rama_berat\%27ta_tika\%27nin_restorasyon_projelerini_inceledi-41890 (accessed: 08.05.2018).

${ }^{24}$ Türkiye-Arnavutluk İlişkileri, http://www.mfa.gov.tr/_turkiye-arnavutluk-siyasi-iliskileri.tr.mfa, (accessed: 03.05.2018).

${ }^{25}$ It is estimated that the Gülen Movement runs schools in approximately 140 countries worldwide, also in Albania. 
the element of national identity for Albanians. We, as the main pillar of our proven national identity, have our blood and language. They are not only few who wrongly believe that we have our dogma the "religion of Albanian is Albania" as a tradition from the period of dictator Hoxha. No, absolutely not. This is, and has been centuries ago a leitmotif of national unity of Albanians. Apart from these, it should be understood that our Islam is European Islam, which means an Islam that is naturalized and in full harmony with the values and principles of western citizenry"26.

He also stipulated that any strategic cooperation with Turkey should be in accordance with Albania's strategic interests.

This declaration is important while it makes clear that, unlike Erdoğan and his followers are willing to, Albanian political and intellectual elite does not consider themselves as Muslim but rather in nation and national categories. This Turkish miscalculation of religion, history and the inhabitants of Albania is significant for the entire "strategic depth" concept and its implementation. The neo-Ottoman aspirations are confronted with reality while significant parts of the society deem the Ottoman rule period as enslavement and tragedy - in the Ottoman Empire Albanians were not allowed to use their own language, and forced to attend Turkish schools only; an allowance to practice their own religion did not overlap with full citizenship laws ${ }^{27}$. This has still an impact today on the perception of both Turkey and her predecessor.

Since the Gülen schools are still operating in Albania one can claim that there is a gap between economic and political relations of the two countries. Turkey remains an important trade partner for Ankara, however Ankara's abilities to impose a concrete political influence are rather limited. Apart from Turkey's domestic problems, growing authoritarianism and internal social and political struggles, all these together, decrease the country's positive image abroad and diminish its perception as a potential model-country.

\section{Conclusions}

With no doubts, the implementation of "strategic depth" conception revitalized Turkey's relations with the Balkan counties together with Albania. The development of economical, trade, diplomatic and tourist relations are clearly visible in this context. Turkey successfully managed to become one of Albania's most important trade partners, however it should be noticed that it is suffering strong competition from European countries. What is more, these relations are highly asymmetrical since for Turkey, Albania is not a top-priority country. In this context, to some extent, the AKP's foreign policy towards the entire region is a continuation of the Kemalist attitude thus remains in accordance with the regional protector's national role - Ankara definitely works in favour of the security and development in the region. On the other hand, the new Turkish activism reflects an active-independ-

${ }^{26}$ Berisha i reagon Erdoganit: Osmanët ishin pushtues - feja e shqiptarit është shqiptaria, (16.05.2015), http:/www.gazetaexpress.com/lajme/berisha-i-reagon-erdoganit-osmanet-ishin-pushtues-feja-e-shqiptarit-eshteshqiptaria-101413/?archive=1, (accessed: 14.01.2017).

${ }^{27}$ P. Misha, Invention of a Nationalism: Myth and Amnesia, in: Albanian Identities: Myth and History, S. Schwandner-Sievers, B. J. Fisher (eds)., London 2002, pp. 33-48. 
ent national role attitude. In fact, Turkey has developed various channels of activism with various regions since 2002. The current Turkish-Albanian relations are only one example of this policy, among many, and shall also be analyzed in the broader context of the entire Balkan Peninsula. The bilateral relations also prove Ankara's limitation both in the "strategic depth" and "active-independency" contexts - Turkey has limited abilities and potential to impose a virtual political influence on other states. While, what the Albanian example proves, Turkey can be successful in trading, references to the Ottoman past are not warmly welcomed however they play an important role in the current AKP's discourse and rhetoric. Thus, one can claim that the current bilateral relations of Turkey and Albania are a mixture of the pragmatic stance and neo-Ottoman aspirations, however the former are beneficial for both parts, and the latter are a result of miscalculation and are perceived with reserve and firm negation.

\section{Bibliography}

Arnavutluk Başbakanı Edi Rama Berat'ta TiKA'nın Restorasyon Projelerini Inceledi, http://www. tika.gov.tr/tr/haber/arnavutluk_basbakani_edi_rama_berat $\% 27$ ta_tika $\% 27$ nin_restorasyon_projelerini_inceledi-41890.

Akoğlu Şişman M., East European countries and Turkey vis-à-vis the EU: a comparative analysis of commercial relations, METU Studies in Development, Vol. 41, No. 3, 2014.

Berisha i reagon Erdoganit: Osmanët ishin pushtues - feja e shqiptarit është shqiptaria, (16.05.2015), http://www.gazetaexpress.com/lajme/berisha-i-reagon-erdoganit-osmanet-ishin-pushtues-fejae-shqiptarit-eshte-shqiptaria-101413/? archive $=1$.

Bishku M.B., Albania and the Middle East, Mediterranean Quarterly, 24, (2), 2013.

Davutoğlu A., Speech on the opening ceremony of the Ottoman Legacy and Balkan Muslim Communities Today Conference, Sarajevo, 16.10.2009.

Davutoğlu A., Stratejik Derinlik. Türkiye'nin Uluslararası Konumu, İstanbul 2001.

Davutoğlu A., Türkiye merkez ülke olmal, Radikal 2004, (online:) http://www.radikal.com.tr/yorum/ turkiye-merkez-ulke-olmali-702116/.

Erdoğan R.T., Speech (30.03.2014, Ankara), http://www.hurriyetdailynews.com/full-text-turkishpm-erdogans-post-election-balcony-speech.aspx?pageID=238\&nID $=64341 \&$ NewsCatID $=338$

Erdoğan R.T., Speech (13.05.2015, Tirana), http://www.tccb.gov.tr/yurt-disi-ziyaretler/355/32313/ arnavutluk.html.

Holsti K.J., National Role Conceptions in the Study of Foreign Policy, International Studies Quarterly, Vol. 14, No. 3, 1970.

Kirişci K., The Transformation of Turkish Foreign Policy: The Rise of the Trading State, New Perspectives on Turkey, No. 40, 2009.

Kramer H., A Changing Turkey: The Challenge to Europe and the United States, Washington 2000

Misha P., Invention of a Nationalism: Myth and Amnesia, in: Albanian Identities: Myth and History, S. Schwandner-Sievers, B. J. Fisher (eds.), London 2002.

Turkish Statistical Institute Data, www.tuik.gov.tr.

Türkeş M., Türkiye'nin Balkan Politikasında Devamlık ve Değjşim, Avrasya Dosyası, Vol. 14, No. 1, 2008.

Türkeş M., Uzgel İ., Türkiye'nin komşuları, Ankara 2002.

Türkiye-Arnavutluk İlişkileri, http://www.mfa.gov.tr/_turkiye-arnavutluk-siyasi-iliskileri.tr.mfa.

Uzgel İ., Balkanlarla İlişskiler, in: Türk Dış Politikası. Kurtuluş Savaşından Bügüne Olgular, Belgeler, Yorumlar, Cilt II 1980-2001, B. Oran (ed.), İstanbul 2005. 
Karol Bieniek, $\mathrm{PhD}$, assistant professor at the Institute of Law, Administration and Economics, Pedagogical University of Cracow. He graduated from M.A. (2006) and $\mathrm{PhD}$ (2011) studies in the field of political science and holds an M.A. degree (2009) in Turkish philology. His scientific interests cover such issues such as: Turkish foreign policy, domestic policy and the party system of the Turkish Republic, Turkish and Muslim minorities in Europe. He is the author of several scientific papers and two books i.e. Turkish Foreign Policy Towards the Balkan States (in Polish, 2008) and The Party System of the Republic of Turkey from 1950-2011 (in Polish, 2013). 